\title{
RELATIONSHIP OF GLUCOSE TO PREVALENCE OF ECG ABNORMALITIES AT BASELINE AND TO 6-YR MORTALITY IN SCOTTISH MALES AGED 45-64 YR
}

\author{
V. M. HaWTHORNE* and W. H. Gilmour $\dagger$
}

(Received 7 June 1979)

\begin{abstract}
Ahstract-A community study of more than 3000 persons screened in the Burgh of Renfrew, Scotland, included 1134 men age 45-64 whose baseline casual glucose level was measured in 1972 and who were followed for $6 \mathrm{yr}$ to determine mortality rate. A positive association was found, in univariate analysis, between baseline glucose level and prevalence of ECG abnormalities as defined both by the London Whitehall Study and the U.S. Pooling Project Study. In multivariate analyses of these cross-sectional data, an association was seen for Whitehall but not Pooling Project abnormalities. No association was found between asymptomatic hyperglycemia and coronary mortality at $6 \mathrm{yr}$, either in univariate, bivariate or multivariate analyses. The clinicallyobserved excess in coronary mortality among those with symptomatic diabetes mellitus was not in evidence among those with asymptomatic hyperglycemia in this group of middle-aged men.
\end{abstract}

\section{INTRODUCTION}

ELUCIDATION of the relationship of hyperglycemia to coronary heart disease requires the examination of many thousands of subjects and their observation over many years. An alternative to large-scale studies, such as those now in progress in mild to moderate hypertension [1], offering a possibility of obtaining conclusive data within a reasonable time, is the parallel examination of comparable data from many centers. The Scottish contribution was a data set comprising prevalence rates of ECG abnormalities at baseline and 6 yr mortality as related to casual blood glucose in a sub-group of a larger study on the natural history and prevention of cardio-respiratory disease in the West of Scotland.

\section{METHODS}

The sample comprised 3000 people aged between 45 and $64 \mathrm{yr}$ on 1 January 1972 , identified by census as residents in the Burgh of Renfrew near Glasgow in the West of Scotland [2]. This represented a response rate of $78.7 \%$. The sample was examined by multiphasic screening in March 1972, as part of a prospective study of the general population. The study was designed primarily to observe the effects of stopping smoking in the $10 \%$ at high risk from cardio-respiratory disease and also to examine the feasibility of accelerating the decline of tuberculosis [3].

All examinees completed a standard questionnaire.ł Height and weight were measured and forced expiratory yolume in $1 \mathrm{sec}$ using a Garthur Vitalograph. A six-lead electrocardiogram (leads I, II, III, aVR, aVL and aVF) was made with the subject sitting. Blood

\footnotetext{
*Professor and Chairman, Department of Epidemiology, The University of Michigan School of Public Health. +Lecturer in Medical Statistics at the University of Glasgow Department of Community Medicine.

Reprint requests to: V. M. Hawthorne, MD, FRCP., FFCM. Department of Epidemiology, School of Public Health, The University of Michigan, 109 Observatory Street, Ann Arbor, Michigan 48109, U.S.A. $\ddagger$ Available on request.
} 
pressure was measured with the subject seated, using the London School of Hygiene and Tropical Medicine sphygmomanometer [4] with a cuff of $12 \times 22 \mathrm{~cm}$. Diastolic was taken at the disappearance of the fifth Korotkoff sound. Observers had been trained to measure blood pressure using special tape records [5]. Finally a tuberculin Tine test (Lederle) was made and a $70 \mathrm{~mm}$ chest X-ray taken.

Blood samples were collected afternoons and evenings. A $10 \mathrm{ml}$ casual sample of venous blood was taken without venous stasis and plasma total cholesterol measured by an autoanalyser technique [6]. Glucose was determined (using whole blood) by the measurement of oxygen consumption [7].

Among 1394 males aged between 45 and 64 yr on the date of screening, 14 were known diabetics. Since interest in this investigation centered on asymptomatic hyperglycemia, these men were not included in this analysis. In addition, 214 men on anti-hypertensive medication at baseline were excluded from the main analyses, since such medication could have altered glucose level. (However, to ascertain whether such exclusion might have biased the findings, the multiple logistic was calculated both excluding and including them.) In addition, 32 other men were excluded who had data missing on variables relevant to this investigation. The remaining 1134 men form the main study group for the purpose of these analyses.

Diabetes was determined by response to questionnaire. Only those answering 'yes' to the question "Are you, or have you ever been diabetic?", or failing to answer, were excluded. Relative weight was calculated as actual weight expressed as a proportion of ideal weight for height and sex, as defined from the Metropolitan Life Insurance Company Tables [8].

For the analyses relating glucose to mortality, six men having ECG evidence at baseline of myocardial infarction (Minnesota Codes 1.1, 1.2) [9], were excluded leaving 1128 men for those analyses.

ECG abnormalities were classified in three groups by Minnesota Code [10]: myocardial infarction-codes 1.1 and 1.2; Whitehall Study criteria for abnormalities-codes 1.1-1.3, 4.1-4.4, 5.1-5.3 and 7.1; and U.S. Pooling Project Major Abnormalities-codes $1.1,1.2,4.1,4.2,5.1,5.2,6.1,6.2,7.1,7.2,7.4,8.1$ and 8.3.

The eighth revision of the International Classification of Disease [11] was used to classify mortality-provided by the N.H.S. Register of the Registrar General for Scotland. Three mortality endpoints were used:

1. All mortality;

2. Cardiovascular mortality (ICD 390-458);

3. Coronary heart disease mortality (ICD 410-414).

Rates of ECG abnormalities and mortality rates for the group as a whole were computed by age-averaging the rates for the four 5-yr age groups.

\section{RESULTS}

Table 1 shows the age distribution of the main study group, as well as of those excluded and displays the numbers excluded for the stated reasons.

Table 1. Characteristics of STUdy population, Renfrew, SCotland

\begin{tabular}{cccccc}
\hline Age group & $\begin{array}{c}\text { Number } \\
\text { of } \\
\text { men }\end{array}$ & Diabetics & $\begin{array}{c}\text { Exclusions } \\
\text { Antihypertensive } \\
\text { treatment }\end{array}$ & $\begin{array}{c}\text { Missing } \\
\text { data }\end{array}$ & $\begin{array}{c}\text { Study } \\
\text { group }\end{array}$ \\
\hline $45-49$ & 389 & 2 & 58 & 10 & 319 \\
$50-54$ & 375 & 3 & 51 & 6 & 315 \\
$55-59$ & 346 & 6 & 55 & 6 & 279 \\
$60-64$ & 284 & $3 \cdot$ & 50 & 10 & 221 \\
Total & 1394 & 14 & 214 & 32 & 1134 \\
\hline
\end{tabular}




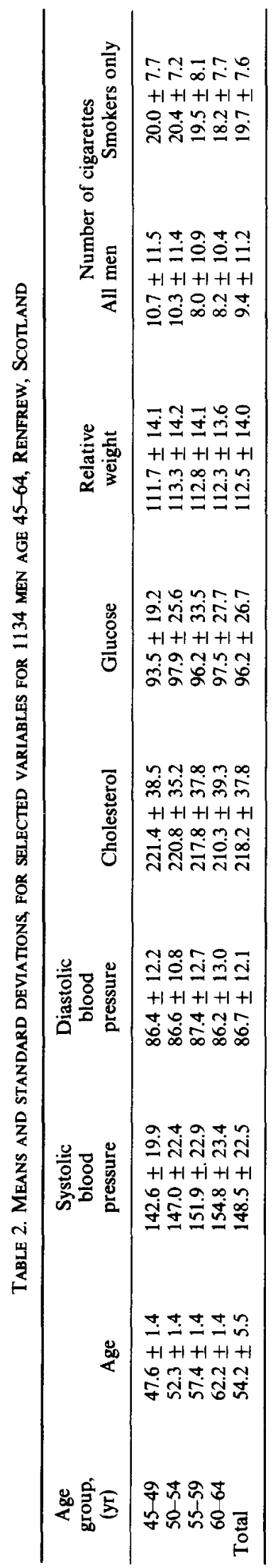




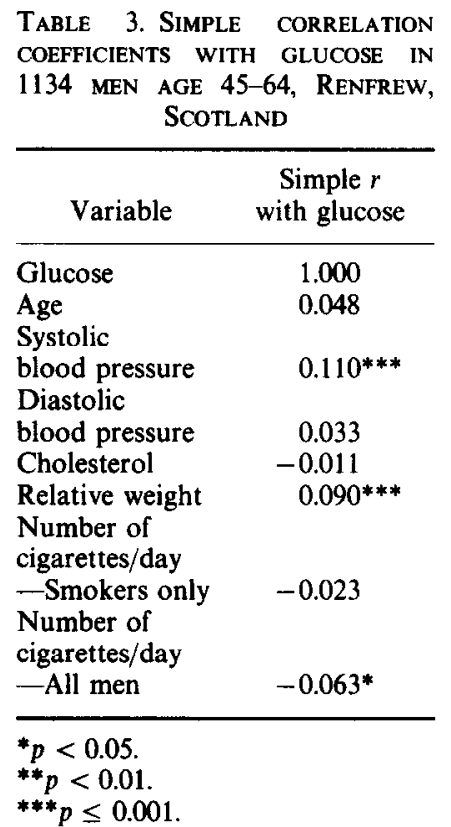

Table 2 gives means and standard deviations, by age group, for the 8 variables of interest-age, systolic blood pressure, diastolic blood pressure, serum cholesterol, glucose, relative weight, number of cigarettes smoked per day by all men and number of cigarettes smoked per day by smokers only.

Table 3 gives simple correlation coefficients with glucose for each of the other variables. Glucose was significantly positively correlated with systolic blood pressure $(p<0.001)$, with relative weight $(p<0.001)$ and with cigarette smoking $(p<0.01)$. Although these correlations were statistically significant, they were of low order.

Tables 4-6 show the relationship between glucose level and prevalence of ECG abnormalities. The number of myocardial infarctions were, in each table, too small to permit meaningful statistical analysis.

Table 4 shows age-adjusted ECG prevalence rates for the quintiles and extreme values of glucose for the study group. There was a trend for higher levels of glucose to be associated with a higher abnormality rate for both Pooling Project Major and Whitehall abnormalities. A chi-squared test for linear trend in abnormality rate yielded a significant result for the Whitehall group $(p<0.05)$. The test for departures from linearity was non-significant, indicating that a straight line is an adequate fit.

TABle 4. Quintiles, eXtreme values OF GLUCOSE AND PREVALENCE OF ECG ABNORMALITIES, 1134 MEN, AGE 45-64, RENFREW, SCOTLAND

\begin{tabular}{ccccccc}
\hline $\begin{array}{c}\text { Quintile of } \\
\text { glucose }\end{array}$ & $\begin{array}{c}\text { Glucose } \\
\text { range } \\
(\mathrm{mg} / \mathrm{dl})\end{array}$ & $\begin{array}{c}\text { Number } \\
\text { of } \\
\text { men }\end{array}$ & $\begin{array}{c}\text { Prevalence of ECG abnormality } \\
\text { Whitehall } \\
\text { Criteria }\end{array}$ & $\begin{array}{c}\text { Pooling Project } \\
\text { Major Abnormalities }\end{array}$ \\
\hline Quintile & & & $*$ & & $*$ \\
1 & $27-80$ & 224 & $8 \dagger$ & $40 \ddagger$ & 10 & 46 \\
2 & $81-88$ & 241 & 13 & 60 & 11 & 49 \\
3 & $89-96$ & 211 & 16 & 77 & 12 & 58 \\
4 & $97-107$ & 230 & 16 & 70 & 16 & 79 \\
5 & $108-518$ & 228 & 19 & 89 & 16 & 73 \\
Lowest 5\% & $27-69$ & 57 & 2 & 35 & 1 & 16 \\
Highest 5\% & $134-518$ & 58 & 9 & 153 & 7 & 123 \\
All Men & $27-518$ & 1134 & 72 & 66 & 65 & 60 \\
\hline
\end{tabular}

* Significant linear trend.

†Number of abnormalities.

†Standardized prevalence rate per 1000 . 
Table 5. Glucose, systolic blood pressure and PReVAlenCe of ECG abNormalities, 1134 men, age 45-64. RENFREW, SCOTLAND

\begin{tabular}{|c|c|c|c|c|c|c|}
\hline Systolic blood & Glucose & Number & & enc & $\mathrm{CG} a \mathrm{~b}$ & \\
\hline $\begin{array}{l}\text { pressure (SBP) and } \\
\text { glucose quintile }\end{array}$ & $\begin{array}{l}\text { range } \\
(\mathrm{mg} / \mathrm{dl})\end{array}$ & $\begin{array}{c}\text { of } \\
\text { men }\end{array}$ & & & $\begin{array}{r}\mathrm{Pc} \\
\mathrm{Majc}\end{array}$ & $\begin{array}{l}\text { ject } \\
\text { nalities }\end{array}$ \\
\hline SBP below median $(\leq 146)$ & & & & & & \\
\hline 1 & $27-80$ & 128 & $4 \dagger$ & $45 \ddagger$ & 6 & 60 \\
\hline 2 & $81-88$ & 148 & 3 & $24^{\circ}$ & 4 & 30 \\
\hline 3 & $89-96$ & 104 & 7 & 73 & 6 & 65 \\
\hline 4 & $97-107$ & 105 & 9 & 78 & 5 & 58 \\
\hline 5 & $108-518$ & 97 & 7 & 85 & 6 & 66 \\
\hline All & $27-518$ & 582 & 30 & 58 & 27 & 54 \\
\hline SBP above median $(>146)$ & & & & & & \\
\hline Qumane & $27-80$ & 96 & 4 & 39 & 4 & 35 \\
\hline 2 & $81-88$ & 93 & 10 & 98 & 7 & 66 \\
\hline 3 & $89-96$ & 107 & 9 & 87 & 6 & 57 \\
\hline 4 & $97-107$ & 127 & 7 & 56 & 11 & 86 \\
\hline 5 & $108-518$ & 131 & 12 & 96 & 10 & 74 \\
\hline All & $27-518$ & 552 & 42 & 74 & 38 & 66 \\
\hline All men & $27-518$ & 11,34 & 72 & 66 & 65 & 60 \\
\hline
\end{tabular}

*Significant linear trend.

†Number of abnormalities.

† Standardized rate per 1000 .

Table 5 divides the study group into two systolic blood pressure groups using the median systolic blood pressure as cutting point, and shows age-adjusted ECG prevalence rates for the quintiles of glucose. A chi-squared test of linear trend in abnormality rates gave a significant result for the Whitehall group with systolic blood pressure below the median $(p<0.05)$. Again the straight line was shown to be an adequate fit. There was a

Table 6. Glucose, smoking and prevalence of ECG abnormalities, 1134 men age 45-64, Renfrew, SCOTLAND

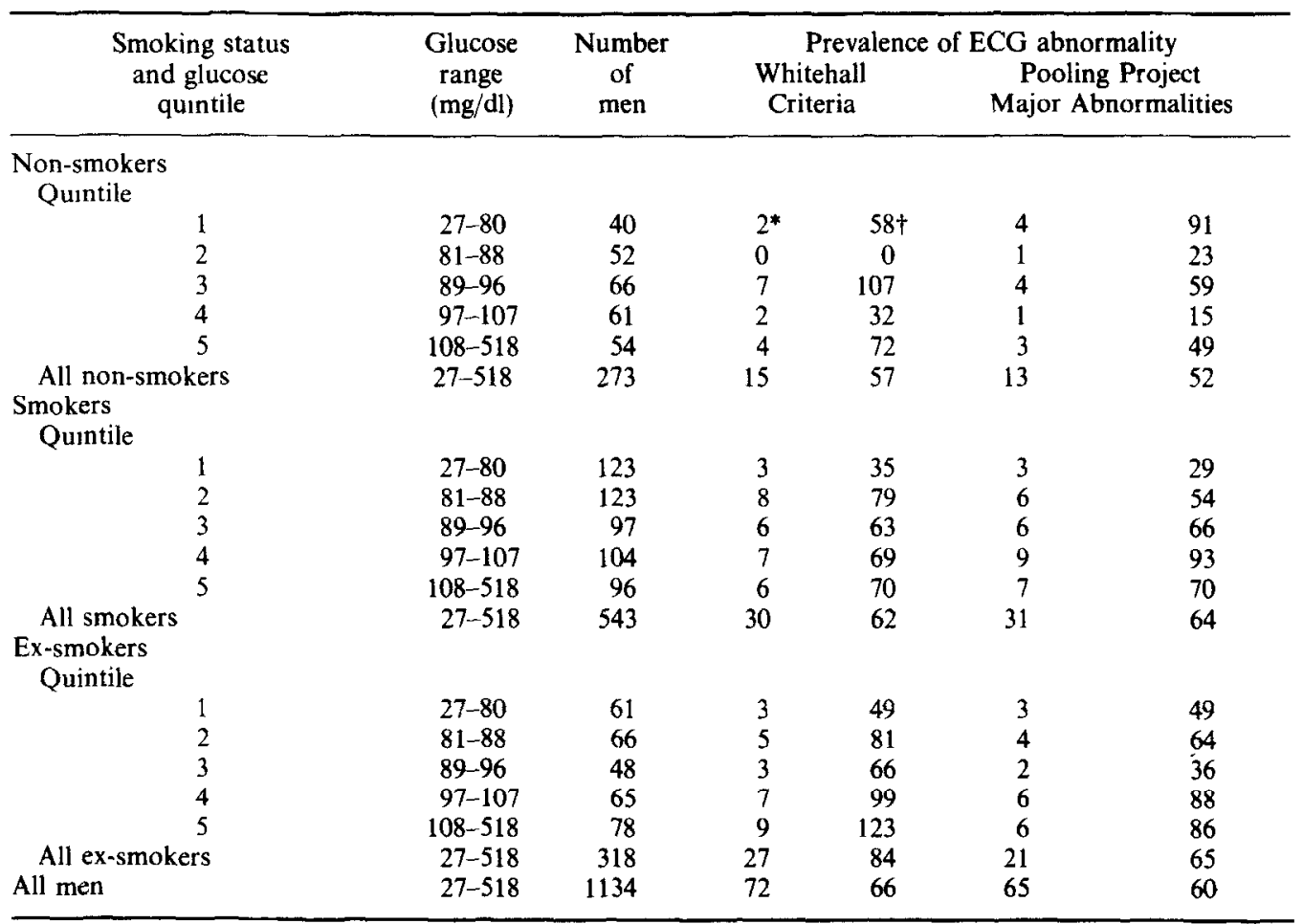

*Number of deaths.

† Standardized death rate per 1000 . 
TABle 7. Multiple logistic analysis, PRevalence of ECG abNoRmalities in 1134 MEN, AGE 45-64 yr, ReNFREw, SCOTland

\begin{tabular}{lcccrr}
\hline \multicolumn{1}{c}{ Variable } & Coeff. $(\beta)$ & S.E. & $t$ & $\begin{array}{r}\text { Non-cases } \\
\text { mean }\end{array}$ & $\begin{array}{r}\text { Cases } \\
\text { mean }\end{array}$ \\
\hline Glucose & \multicolumn{2}{c}{ Whitehall Criteria- -72 cases } & & \\
Age & 0.0119 & 0.0046 & $2.58^{* *}$ & 95.5 & 105.2 \\
Systolic pressure & 0.0653 & 0.0230 & $2.84^{* *}$ & 54.0 & 56.1 \\
Relative weight & 0.0106 & 0.0057 & 1.87 & 148.0 & 156.6 \\
Cholesterol & 0.0155 & 0.0092 & 1.69 & 112.2 & 117.2 \\
Cigarettes/day & 0.0107 & 0.0033 & $3.22^{* *}$ & 217.2 & 232.5 \\
Ex-smoking & 0.0075 & 0.0131 & 0.57 & 9.5 & 7.9 \\
Constant & 0.3974 & 0.3199 & 1.24 & & \\
& -13.47 & & & & \\
Glucose & & & & & \\
Age & Pooling Project & Major Abnormalities-65 & cases & \\
Systolic pressure & 0.0025 & 0.0048 & 0.51 & 95.9 & 99.2 \\
Relative weight & 0.0857 & 0.0241 & $3.55^{* * *}$ & 54.0 & 56.9 \\
Cholesterol & 0.0104 & 0.0060 & 1.74 & 148.1 & 155.9 \\
Cigarettes/day & 0.0109 & 0.0096 & 1.13 & 112.4 & 114.4 \\
Ex-smoking & -0.0078 & 0.0035 & $-2.26^{*}$ & 218.8 & 207.6 \\
Constant & 0.0172 & 0.0137 & 1.26 & 9.4 & 9.7 \\
\hline
\end{tabular}

$$
\begin{aligned}
& { }^{*} p<0.05 \\
& { }^{* *} p<0.01 \\
& { }^{* *} p \leq 0.001
\end{aligned}
$$

similar trend in the above-median systolic blood pressure group for Pooling Project Major Abnormalities but it was not statistically significant.

Table 6 splits the study group according to smoking habit and shows age-adjusted ECG abnormality rates for the quintiles of glucose. There were no apparent trends among non-smokers and the trends for high glucose to be associated with higher abnormality rates among smokers and ex-smokers were not significant.

Table 7 shows the multiple logistic analysis for ECG abnormalities taking into account the variables age, systolic blood pressure, cholesterol, glucose, relative weight, number of cigarettes smoked per day, and ex-smoking, which is a variable taking the value ' 0 ' for

\begin{tabular}{|c|c|c|c|c|c|}
\hline Variable & Coeff. $(\beta)$ & S.E. & $\mathbf{t}$ & $\begin{array}{c}\text { Non-cases } \\
\text { mean }\end{array}$ & $\begin{array}{l}\text { Cases } \\
\text { mean }\end{array}$ \\
\hline \multicolumn{6}{|c|}{ Whitehall Criteria-123 cases } \\
\hline Glucose & 0.0094 & 0.0038 & $2.50^{*}$ & 95.6 & 102.6 \\
\hline Age & 0.0670 & 0.0177 & $3.78^{* * *}$ & 54.1 & 56.2 \\
\hline Systolic pressure & 0.0109 & 0.0043 & $2.54^{*}$ & 148.4 & 157.4 \\
\hline Relative weight & 0.0132 & 0.0071 & 1.86 & 112.2 & 116.4 \\
\hline Cholesterol & 0.0094 & 0.0026 & $3.66^{* * *}$ & 218.4 & 231.8 \\
\hline Cigarcttes/day & 0.0131 & 0.0103 & 1.27 & 9.5 & 9.3 \\
\hline Ex-smoking & 0.2682 & 0.2505 & 1.07 & & \\
\hline Constant & -12.40 & & & & \\
\hline \multicolumn{6}{|c|}{ Pooling Project Major Abnormalities--105 cases } \\
\hline Glucose & 0.0004 & 0.0040 & 0.10 & 96.1 & 97.6 \\
\hline Age & 0.1020 & 0.0191 & $5.33^{* * *}$ & 54.0 & 57.2 \\
\hline Systolic pressure & 0.0077 & 0.0046 & 1.67 & 148.6 & 156.2 \\
\hline Relative weight & 0.0134 & 0.0076 & 1.76 & 112.4 & 115.0 \\
\hline Cholesterol & -0.0024 & 0.0027 & -0.88 & 219.9 & 216.4 \\
\hline Cigarettes/day & 0.0169 & 0.0111 & 1.52 & 9.5 & 9.7 \\
\hline Ex-smoking & 0.3531 & 0.2692 & 1.31 & & \\
\hline Constant & -10.62 & & & & \\
\hline
\end{tabular}

Table 7A. Multiple logistic analysis, prevalence of ECG abnormalities in 1348 MEN AGE 45-64 yr: INCLUDING THOSE ON ANTI-HYPERTENSIVE TREATMENT

$$
\begin{aligned}
& { }^{*} p<0.05 \\
& { }^{* *} p<0.01 \\
& { }^{* *} p \leq 0.001
\end{aligned}
$$




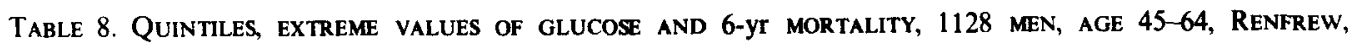
SCOTLAND

\begin{tabular}{|c|c|c|c|c|c|c|c|c|}
\hline \multirow[b]{2}{*}{ Quintule } & \multirow[t]{2}{*}{$\begin{array}{l}\text { Glucose } \\
\text { range } \\
(\mathrm{mg} / \mathrm{dl})\end{array}$} & \multirow[t]{2}{*}{$\begin{array}{c}\text { Number } \\
\text { of } \\
\text { men }\end{array}$} & \multicolumn{2}{|c|}{$\begin{array}{c}\text { All } \\
\text { mortality }\end{array}$} & \multicolumn{2}{|c|}{ 6-yr mortality } & \multicolumn{2}{|c|}{$\begin{array}{c}\text { Coronary } \\
\text { heart disease }\end{array}$} \\
\hline & & & & & & & & \\
\hline 1 & $27-80$ & 222 & $8^{*}$ & $48+$ & 5 & 29 & 4 & 22 \\
\hline 2 & $81-88$ & 241 & 16 & 68 & 8 & 33 & 6 & 26 \\
\hline 3 & $89-96$ & 211 & 13 & 65 & 4 & 20 & 3 & 15 \\
\hline 4 & $97-107$ & 227 & 11 & 53 & 5 & 25 & 3 & 16 \\
\hline 5 & $108-518$ & 227 & 12 & 58 & 7 & 35 & 6 & 31 \\
\hline Lowest $5 \%$ & $27-69$ & 57 & 3 & 69 & 2 & 44 & 2 & 44 \\
\hline Highest $5 \%$ & $134-518$ & 58 & 3 & 73 & 1 & 28 & 0 & 0 \\
\hline All men & $27-518$ & 1128 & 60 & 59 & 29 & 28 & 22 & 22 \\
\hline
\end{tabular}

*Number of deaths.

†Standardized death rate per 1000 .

non-smokers and current smokers and ' 1 ' for ex-smokers. Cholesterol, age and glucose were significantly positively associated with Whitehall abnormalities while cholesterol was significantly negatively associated with Pooling Project Major Abnormalities.

In order to determine whether exclusion of the large group of men on anti-hypertensive trcatment had obscured any associations, the multivariate analyses were recomputed including those men (Table 7A). Glucose continued to be positively and significantly associated with Whitehall abnormalities and to show no association with Pooling Project Major Abnormalities. The 214 treated hypertensive men added 40 cases to the previous 65 Pooling Project Major Abnormalities found in 1134 men. With this larger number of cases the previous negative association of cholesterol with the abnormality was no longer statistically significant. Age remained a significant factor.

Tables 8-11 inclusive show analyses similar to those in Tables 4-7, with 6-yr mortality instead of prevalence of ECG abnormalities as the end point. There was no evidence from Tables 8,9 or 10 to suggest that higher mortality rates were associated with higher glucose levels.

Table 9. Glucose, Systolic Blood PRessure and 6-yt mortality, 1128 men, age 45-64, Renfrew, SCOTLAND

\begin{tabular}{|c|c|c|c|c|c|c|c|c|}
\hline $\begin{array}{c}\text { Systolic blood } \\
\text { pressure (SBP) } \\
\text { and glucose } \\
\text { quintile }\end{array}$ & $\begin{array}{l}\text { Glucose } \\
\text { range } \\
\text { (mg/dl) }\end{array}$ & $\begin{array}{c}\text { Number } \\
\text { of } \\
\text { men }\end{array}$ & \multicolumn{2}{|c|}{$\begin{array}{c}\text { All } \\
\text { mortality }\end{array}$} & \multicolumn{2}{|c|}{$\begin{array}{l}\text { 6-yr mortality } \\
\text { Cardiovascular }\end{array}$} & \multicolumn{2}{|c|}{$\begin{array}{c}\text { Coronary } \\
\text { heart disease }\end{array}$} \\
\hline 1 & $27-80$ & 126 & $2^{*}$ & $31 t$ & 0 & 0 & 0 & 0 \\
\hline 2 & $81-88$ & 148 & 10 & 71 & 6 & 46 & 5 & 40 \\
\hline 3 & $89-96$ & 104 & 6 & 66 & 2 & 17 & 2 & 17 \\
\hline 4 & $97-107$ & 104 & 4 & 47 & 2 & 28 & 1 & 21 \\
\hline 5 & $108-518$ & 97 & 1 & 14 & 0 & 0 & 0 & 0 \\
\hline $\begin{array}{l}\text { All } \\
\text { SBP above } \\
\text { median }(>146) \\
\text { Quintile }\end{array}$ & $27-518$ & 579 & 23 & 49 & 10 & 20 & 8 & 17 \\
\hline 1 & $27-80$ & 96 & 6 & 60 & 5 & 49 & 4 & 37 \\
\hline 2 & $81-88$ & 93 & 6 & 65 & 2 & 21 & 1 & 10 \\
\hline 3 & $89-96$ & 107 & 7 & 61 & 2 & 16 & 1 & 8 \\
\hline 4 & $97-107$ & 123 & 7 & 55 & 3 & 23 & 2 & 15 \\
\hline 5 & $108-518$ & 130 & 11 & 85 & 7 & 57 & 6 & 50 \\
\hline All & $27-518$ & 549 & 37 & 67 & 19 & 33 & 14 & 25 \\
\hline All men & $27-518$ & 1128 & 60 & 59 & 29 & 28 & 22 & 22 \\
\hline
\end{tabular}

*Number of deaths

† Standardized death rate per 1000 
In the multiple logistic analyses in Table 11, age and systolic pressure showed the strongest association with mortality. Cigarette smoking (present or past) also showed positive association with cardiovascular and coronary mortality. However glucose was not found to be associated with any of the mortality endpoints.

When those on anti-hypertensive medication were included (Table 11A), age remained positively associated with mortality and glucose showed a slight non-significant negative association with CHD mortality. The anomalous finding that, with inclusion of known hypertensives, the former strong positive association of systolic pressure with mortality disappeared, could be attributed to the lower mean pressure in the treated hypertensives, who contributed heavily to the events.

Table 10. Glucose, smoking and mortality, 1128 men, age 45-64, Renfrew, SCotland

\begin{tabular}{|c|c|c|c|c|c|c|c|c|}
\hline \multirow{2}{*}{$\begin{array}{c}\begin{array}{c}\text { Smoking status } \\
\text { and glucose } \\
\text { quintile }\end{array} \\
\begin{array}{c}\text { Non-smokers } \\
\text { Ouintile }\end{array}\end{array}$} & \multirow[t]{2}{*}{$\begin{array}{c}\text { Glucose } \\
\text { range } \\
\text { (mg/dl) }\end{array}$} & \multirow[t]{2}{*}{$\begin{array}{c}\text { Number } \\
\text { of } \\
\text { men }\end{array}$} & \multicolumn{2}{|c|}{$\begin{array}{c}\text { All } \\
\text { mortality }\end{array}$} & \multicolumn{2}{|c|}{ 6-yr mortality } & \multicolumn{2}{|c|}{$\begin{array}{c}\text { Coronary } \\
\text { heart disease }\end{array}$} \\
\hline & & & & & & & & \\
\hline 1 & $27-80$ & 39 & $2^{*}$ & $63 \dagger$ & 0 & 0 & 0 & 0 \\
\hline 2 & $81-88$ & 52 & 1 & 23 & 0 & 0 & 0 & 0 \\
\hline 3 & $89-96$ & 66 & 3 & 42 & 0 & 0 & 0 & 0 \\
\hline 4 & $97-107$ & 61 & 1 & 13 & 0 & 0 & 0 & 0 \\
\hline 5 & $108-518$ & 54 & 3 & 51 & 1 & 19 & 1 & 19 \\
\hline All non-smokers & $27-518$ & 272 & 10 & 39 & 1 & 4 & 1 & 4 \\
\hline \multirow{2}{*}{\multicolumn{9}{|c|}{ Smokers }} \\
\hline & & & & & & & & \\
\hline 1 & $27-80$ & 123 & 4 & 51 & 3 & 37 & 2 & 23 \\
\hline 2 & $81-88$ & 123 & 9 & 68 & 4 & 29 & 3 & 23 \\
\hline 3 & $89-96$ & 97 & 10 & 118 & 4 & 46 & 3 & 34 \\
\hline 4 & $97-107$ & 101 & 9 & 107 & 4 & 45 & 3 & 37 \\
\hline 5 & $108-518$ & 96 & 4 & 46 & 2 & 23 & 1 & 11 \\
\hline All smokers & $27-518$ & 540 & 36 & 77 & 17 & 36 & 12 & 26 \\
\hline \multicolumn{9}{|l|}{ Ex-smokers } \\
\hline \multicolumn{9}{|l|}{ Quintile } \\
\hline 1 & $27-80$ & 60 & 2 & 33 & 2 & 33 & 2 & 33 \\
\hline 2 & $81-88$ & 66 & 6 & 81 & 4 & 54 & 3 & 44 \\
\hline 3 & $89-96$ & 48 & 0 & 0 & 0 & 0 & 0 & 0 \\
\hline 4 & $97-107$ & 65 & 1 & 12 & 1 & 12 & 0 & 0 \\
\hline 5 & $108-518$ & 77 & 5 & 85 & 4 & 66 & 4 & 66 \\
\hline All ex-smokers & $27-518$ & 316 & 14 & 48 & 11 & 37 & 9 & 32 \\
\hline All & $27-518$ & 1128 & 60 & 59 & 29 & 28 & 22 & 22 \\
\hline
\end{tabular}

*Number of deaths.

†Standardized death rate per 1000 .

\section{COMMENTS}

In Renfrew, multivariate analyses did not consistently demonstrate an association between baseline glycemia and coronary or cardiovascular death rates. Univariate crosssectional analyses showed a positive association between blood glucose and the prevalence of ECG abnormality as defined both by the London Whitehall Study and the U.S. Pooling Project. Preliminary prevalence data now available from an additional 3188 males, age 45-64 yr show similar trends in the relation between baseline glucose levels and these end points. Both the Renfrew [1] and Paisley [12] studies are prospective, and together comprise 15,466 males and females identified by census in the general population. It would seem important that our collaboration continue in order to answer the questions that remain unanswered in this report and until sufficient mortality has accumulated not only in the West of Scotland and Chicago where mortality and morbidity are high but also in other participating countries. 

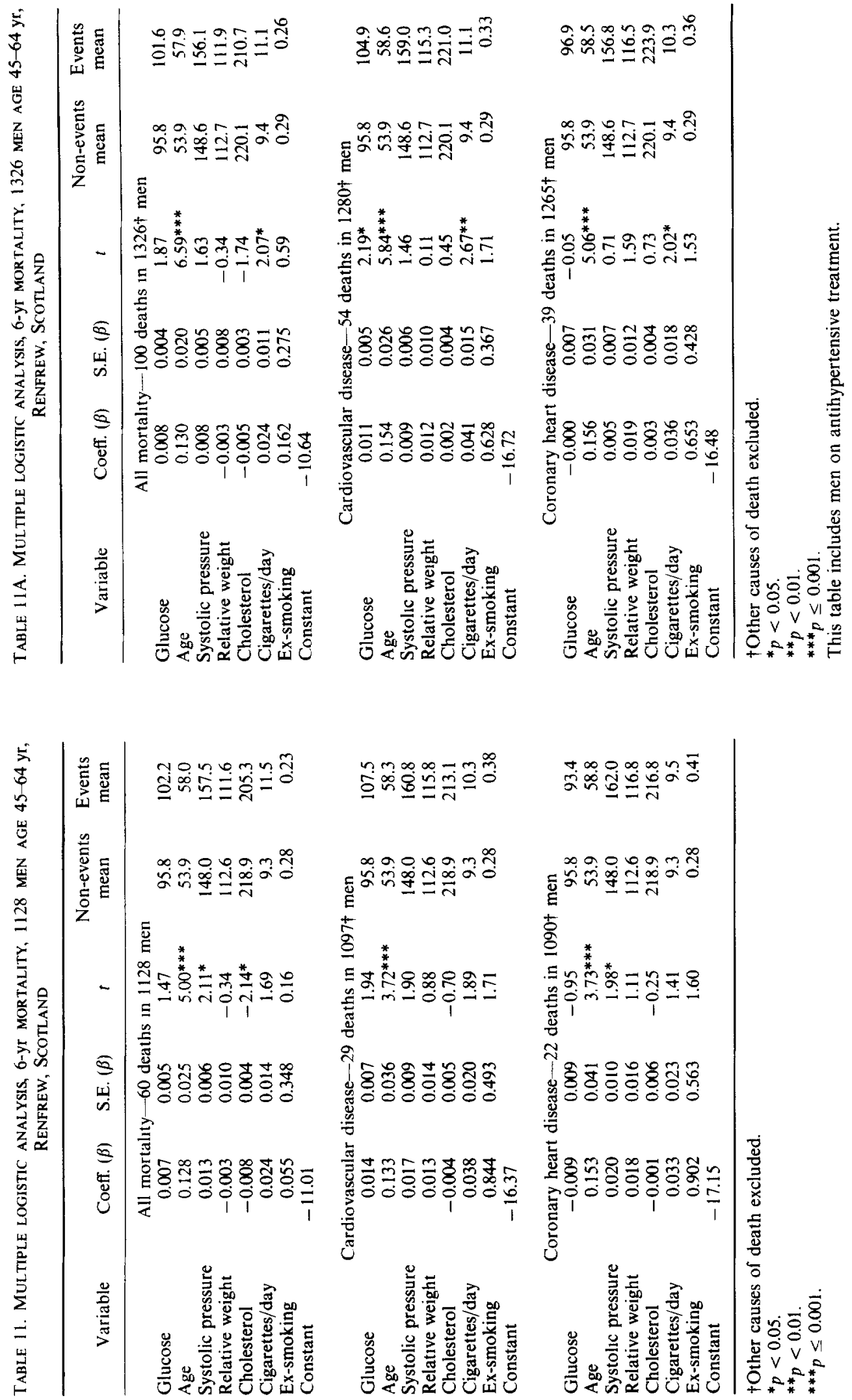


\section{REFERENCES}

1. Report of MRC Working Party on Mild to Moderate Hypertension: Randomised controlled trial of treatment for mild hypertension: design and pilot trial. Br Med J 1:1437-1440, 1977

2. Hawthorne VM, Greaves DA, Beevers DG: Blood pressure in a Scottish town. Br Med J 3:600-603, 1974

3. Hawthorne VM: An epidemiological method to improve tuberculosis control. Scot Med J 14:222-227, 1969

4. Rose GA, Holland WW, Crowley EA: a sphygmomanometer for epidemiologists. Lancet $1: 296-300,1964$

5. Rose GA: Standardisation of observers in blood-pressure measurement. Lancet 1:673-674, 1965

6. Annan W, Isherwood DM: An automated method for the direct determination of total serum cholesterol. J Med Lab Tech 26: 202-211, 1969

7. Kaddish AH, Little RL, Sternberg JC: A new and rapid method for the determination of glucose by measurement of rate of oxygen consumption. Clin Chem 14:116-131, 1968

8. New weight standards for men and women. Stat Bull Metropol Life Ins Co 40:1-4, Nov-Dec 1959

9. Blackburn H, Keys A, Simonson E, Rautaharju P, Punsar S: The electrocardiogram in population studies, a classification system. Circulation 21:1160-1175, 1960

10. Rose G, Blackburn H: Cardiovascular Survey Methods WHO Monograph Series No. 56, Geneva: World Health Organization, 1968

11. Manual of International Statistical Classification of Diseases, Injuries and Causes of Death, Eighth Revision. Geneva: World Health Organization, 1969

12. Hawthorne VM: Epidemiology and treatment of hypertension in the community. Curr Med Res Opin 5 (Suppl 1): 109, 1977 